\title{
A Novel Transdermal Delivery System based on a Bile Acid- Conjugated Nanoparticle Model for Cosmetics
}

\author{
Dongmyong Kim ${ }^{1 *}$, Jongseong Yoon ${ }^{1}$, Seoju $\mathrm{Kim}^{2}$, Hosoon $\mathrm{Choi}^{2}$, Insuk $\mathrm{Han}^{3}$ \\ ${ }^{1} \mathrm{XYZ}$ Human Science Research Institute, College of Medicine, Hanyang University, Seoul, Korea \\ ${ }^{2}$ Department of Internal Medicine, College of Medicine, Hanyang University, Seoul, Korea \\ ${ }^{3}$ Department of Chemistry, College of Natural Sciences, Hanyang University, Seoul, Korea
} \begin{abstract}
04763, Korea
Tel.: +82 220170806

Fax: +82 226494524

Email: hapyvirus@naver.com

Received December 12, 2018

Revised February 21, 2019

Accepted February 25, 2019

Published March 30, 2019
\end{abstract}

*Corresponding author: Dongmyong Kim XYZ Human Science Research Institute, College of Medicine, Hanyang University, 222 Wangsimni-ro, Seongdong-gu, Seoul

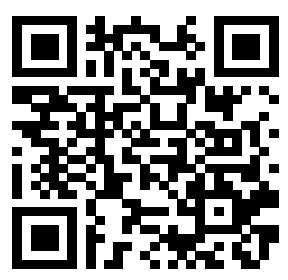

\begin{abstract}
Purpose: We assessed the in vivo efficacy of a cosmetic formulation comprising a transdermal delivery system of model bile acid nanoparticles after the development of a phytosphingosine-1-phosphate (PhS1P)/phytosterol (PS) carrier based on chemically modified lecithin with sodium deoxycholate, using cholesterol as a hydrophobic component. Methods: PhS1P/PS was loaded into a bile acidconjugated nanoparticle (PhS1P/PS-MBA nanoparticle) model via sonication. Franz diffusion cell experiment was performed to evaluate the skin penetration efficacy of the prepared nanoparticles and to comprehend the feasibility of applying the raw material. The nanoparticles were confirmed using a particle size analyzer, scanning electron microscope, and high-performance liquid chromatography system. In order to understand the effectiveness of the nanoparticles on the skin, we performed an in vivo test in human volunteers using the finished product. The elasticity, thickness, and dermal density of the applied skin were examined by using Cutometer (Courage+Khazaka electronic GmbH, Germany). Results: We confirmed through our tests that the nanoparticles could be successfully prepared with $85 \%$ yield and were approximately $120.3 \mathrm{~nm}$ in diameter. The product showed more efficient skin permeation than the control, thereby suggesting an easier uptake within the cells and a concomitant fast release of cleaved PhS1P/PS into the human skin. Safety assessment, elasticity, thickness, and dermal density of the nanoparticles on the human skin were examined to test the possible applicability of the nanoparticles to cosmetics. No adverse symptoms were observed. Conclusion: It is therefore recommended that cosmetic products should use PhS1P/PS-MBA nanoparticles in their formulation for easier absorbability into the skin. Our experiment confirms that this new material may have valuable influences on the human skin.
\end{abstract}

Keywords: Sphingosine phosphate, Phytosterol, Model bile acid, Nanoparticle, Transdermal delivery system

\section{Introduction}

최근 서구식 생활방식이나 실내외 환경변화 등으로 자신의 피 부가 민감성 피부(sensitive skin)라고 생각하는 소비자가 많고 이에 대한 연구가 꾸준히 증가하는 추세이다.

한 연구에서 20-40세 피험자 50명을 대상으로 민감성 피부군 20 명, 비민감성 피부군 30 명을 구분하고 피부장벽기능 및 세라 마이드 함량을 분석한 결과, 민감성 피부군은 측정한 모든 부위
에서 경표피 수분손실량(transepidermal water loss, TEWL)의 차이가 없는 것으로 나타났으나 세라마이드 함량을 분석한 결과 에서는 모든 측정 부위에서 세라마이드가 감소되어 있음을 보였 다. 특히 얼굴 부위에서의 차이는 통계적으로도 유의하거나 뚜렷 하게 나타났다(Cho et al., 2012).

또한 다양한 피부염에서의 세라마이드 함량을 확인한 결과, 겨 울건조증, 접촉피부염, 아토피피부염 등 여러 피부염에서 세라마 이드 총 함량이 감소되어 있음이 보고된바 있다(Coderch et al., 
2003). 이는 곧 세라마이드 감소에 의한 피부장벽기능의 약화가 피부염의 주요 원인으로 설명될 수 있음을 의미하며, 특히 민감 성 피부 중 피부염이 동반된 경우에는 적절한 피부과 치료를 받 는 것이 필요하다. 이와 동시에 스테로이드 성분을 함유하지 않 은 화장품을 사용함으로써 부족한 피부장벽기능을 보강해 주어 야 하고, 이에 따라 피부장벽기능 이상을 효과적으로 개선할 수 있는 화장품 개발이 시급하다.

담즙산(bile acid)의 주성분인 sodium deoxycholate와 cholesterol 등은 간에서 생성되어 담낭에 저장되었다가 소화관 으로 분비되는 지방성분들을 빠르게 감싸 유화를 통해 물리적 분 해를 돕는 물질로서, 지방성분들 자체의 표면적을 늘려 리파아 제의 화학적 지방 분해 작용 촉진을 유도하는 기능을 한다. 또 한 담낭에서 마이셀 형태로 존재하였다가 지방성분들을 유화시 키고 분해할 때 빠르게 작용하여 소화 및 흡수를 용이하게 할 뿐 만 아니라 위산을 중화시키고 다양한 효소작용을 촉진시키는 역 할도 수행한다(Stamp \& Jenkins, 2008; Hofmann \& Small, 1967; Hofmann \& Mysels, 1992; Setchell et al., 1988). 이 전의 연구에서 이러한 것에 착안하여 생체모방기술(biomimetic technology)로 유사 담즙산 즉, 모델 담즙산(model bile acid)을 합성하였고(Hjelm et al., 1995; Kim, 2003; Mi et al., 2003; Nurunnabi et al., 2016; Roda et al., 1983), 본 연구에서는 이러한 담즙산의 원리를 이용하여 새로운 모델 담즙산을 개발 하여 생체적 친화도가 높은 피부전달체(transdermal delivery system, TDS)의 소재로 사용하였다.

Phytosphingosine-1-phosphate (PhS1P)는 피부에 상처 가 나거나 극심한 스트레스에 노출되면 이것을 극복하기 위해 세 포의 사멸을 방지하고 활성화하는데 기여한다. 뿐만 아니라 진피 세포의 증식을 통한 콜라겐 생성을 촉진하고, 자외선에 노출되어 사멸되는 세포를 보호하며 방사능 피폭으로 인한 유전자 손상을 억제하여 불임 및 기형아 출산을 예방한다는 연구결과가 발표된 바 있다. 이와 같은 효능을 가진 $\mathrm{PhS} 1 \mathrm{P}$ 는 화장품 및 의약품 원료 로 주목 받고 있으나, $1 \mathrm{~g}$ 당 4 억원이나 되는 가격 때문에 상용화 에 어려움이 있어 최근에는 비교적 저렴한 glycosphingo lipids 를 구입하여 화장품 원료로 사용하고 있다(Chung et al., 2000; Lee et al., 2012; Shin et al., 2007).

Phytosterol (PS)은 식물성스테롤 이며 콜레스테롤과 구조적 으로 비슷하여 세포막의 필수 구성성분이다. 대표적인 물질은 $\beta$-sitosterol, campesterol, stigmasterol 등이 있다. 이들 중에 $\beta$-sitosterol은 피부에서 항염효과가 있음이 오래 전부터 알려져 있었으며 아토피피부염 마우스 모델에서 항염효과가 우수함이 입 증되어 세라마이드 등의 피부지질성분에 의한 피부장벽 회복기 능과 함께 항염 효과를 줄 수 있는 화장품 원료로 사용하고 있다 (Bouic, 2001; Han et al., 2014; Loizou et al., 2010; Pata et al., 2010; Pyne \& Pyne, 2000).
이전의 연구에서 PhS1P와 PS가 두개의 acid-cleavable linkage를 통해 di-block 공중합체의 말단에 부착하여 담즙 산 성분과 5 5 -hydrogen bond 및 cis-A/B configuration bond를 형성하는 입자 상태로 존재하며, 평균직경이 약 120.3 $\mathrm{nm}$ 이고 임계 농도는 $1.5 \mathrm{mg} / \mathrm{mL}$ 임을 확인하였고, 이를 'PhS1P/PS conjugated model bile acid (PhS1P/PS-MBA) nanoparticle, 모델 담즙산-PhS1P/PS 나노입자'로 명명하였 다(Kim et al., 2017). 또한, 모델 담즙산-PhS1P/PS 나노입자 가 산성 조건에서 hydrogen bond와 결합되어 십게 손상되지 않 는 구조로 인간의 섬유아세포내로 안정적으로 빠르게 흡수되어 $\mathrm{PhS1P/PS를} \mathrm{방출하고} \mathrm{있음을} \mathrm{보고하였다(Kim} \mathrm{et} \mathrm{al.,} \mathrm{2018;}$ Yun et al., 2017; Yun \& Kim, 2018a; Yun \& Kim, 2018b; Yun et al., 2018).

본 연구에서는 피부장벽기능에서 가장 중요한 세라마이드 등 주요 구성물질 혼합물의 최적화 비율을 활용하여 $\mathrm{PhS} 1 \mathrm{P} / \mathrm{PS}$ 를 피부에 고함량 및 속효성으로 안전하게 흡수될 수 있도록 모델 담즙산-PhS1P/PS 나노입자를 제조 후 제형 기술을 적용하여 피부 흡수 증진이 우수한 화장품을 개발하고자 하였다. 또한, 피 부미용 효과를 측정하기 위한 피부자극, 피부 탄력 개선, 피부 두 께 증가, 피부치밀도 개선에 관하여 연구를 진행하였다.

현재 화장품 업계는 미백, 주름, 항산화, 항노화 등의 기능성 화장품의 신소재 개발과 더불어 실제적으로 피부에 적용 시 피부 전달체(transdermal delivery system)로 경피 흡수율을 높이려 는 여러 기반기술들을 시도하고 있다(Chung \& Han, 2014; Lee et al., 2016). 그러나 이들 선행 기술들은 경피 흡수는 촉진시켜 도 안정성에 대한 문제와 입자크기, 포집효율 등 제제의 문제점 이 있고 실제적으로 피부에 속효성을 기대하기가 어려우며, 피부 투과율을 높이고 원래의 유효성분의 효과를 최대화하기 위한 피 부전달체 기술에 대한 연구는 아직 미흡하다. 지금까지의 연구들 이 입자 크기를 작게 만들고 투과율을 높여 경피 흡수율을 증가 시키는 것에 집중되었다면, 이제는 더 나아가 최종 흡수된 성분 의 효과가 얼마나 유지되고 고함량으로 안전한지에 대한 연구가 필요하다고 사료된다.

본 연구를 통하여 우리는 모델 담즙산을 사용하여 피부에 자 극을 주지 않으면서도 빠르게 흡수를 촉진시키고 효과를 극대화 할 수 있는 새로운 피부전달체 기술을 개발하고 이와 더불어 인 체 피부세포 흡수율 및 피부 개선능이 우수한 화장품 소재 및 제 품을 개발하고자 하였다.

\section{Methods}

\section{1. 실험재료 및 사용기기}

본 연구에 사용한 주요 시약은 phytosphingosine- 
1st step: solutions preparation

1) Taurocholic acid: $5.78 \mathrm{~g}$ in $25 \mathrm{~mL} \mathrm{MeOH} / \mathrm{H}_{2} \mathrm{O}(85: 15, \mathrm{v} / \mathrm{v}): 430 \mathrm{mM}$

2) Lecithin: $100 \mathrm{mg} / \mathrm{mL}$ in chloroform

3) Cholesterol: (purified by methanol down method) $500 \mathrm{mg} / 10 \mathrm{~mL}$ chloroform

For $50 \mathrm{~mL}$ model bile acid: $2.25 \mathrm{~mL}$ taurocholic acid solution $+1.8 \mathrm{~mL}$ lecithin

solution $+1.05 \mathrm{~mL}$ cholesterol solution

2nd step: model bile acid preparation

Add solution to glass tube with teflon cap

Evaporate solution under nitrogen gas until think and sticky (yellow wish)

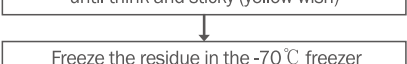
for at least 1 hour

Open the tube and lyophilize the tube overnight

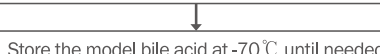

Store the model bile acid at $70^{\circ} \mathrm{C}$ until needed

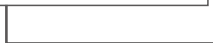

In a water bath $\left(50-60^{\circ} \mathrm{C}, 4-6 \mathrm{~h}\right)$

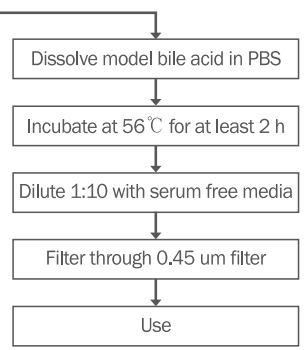

Figure 1. A schematic illustrating the manufacturing process of MBA.

MBA was prepared by using the sodium deoxycholate, lecithin, and cholesterol. It used as a material of a novel transdermal system. MBA, model bile acid.

1-phosphate (PhS1P; Kikkoman Biochemifa Ltd, Japan), phytosterol (PS; CN LAB Inc., China), sodium deoxycholate (SDC; Orient Stars LCC, USA), cholesterol (yeast cholesterol JSQI; ACB Active Concepts LCC, USA), hydrogenated lecithin (Lipoid P75-3; Lipoid GmbH, Germany), tetrahydrofuran (THF; Sigma-Aldrich, USA)이 며, 세포실험 및 형광발색용 시약은 phosphate buffer saline (PBS; Welgene Inc., Korea), propidium iodide (PI; SigmaAldrich), Dulbecco Modified Eagle Medium (DMEM; Gibco-BRL, USA), 4',6-diamidino-2-phenylindole (DAPI; Invitrogen, USA)를 사용하였다.

제조된 나노입자의 입도 분포는 Zeta Potential (ELS-Z; Photal Otsuka Electronics inc., Japan)로 측정하였고, 나노입 자의 형태는 모양을 관찰하기 위하여 SEM (JEM-1010 ; JEOL Ltd., Japan) 장비를 사용하였다. 또한, 나노입자 내의 $\mathrm{PhS} 1 \mathrm{P}$ 와 PS의 봉입량과 포집효율은 HPLC (Agilent 1200 Series; Agilent Technologies, Germany)를 통해 분석하였다.

한편, 형광물질 합성을 위하여 초음파분산기(Ultrasonic processor-VC 505; Sonics \& Materials Inc., USA)를 사 용하였고, 형광 발색 이미지는 형광현미경(Leica DM-4000; Leica Microsystems Ltd., Germany)으로 관찰하였다.그리 고 피부상태를 측정하기 위해서 Cutometer (Cutometer MPA580; Courage+Khazaka electronic GmbH, Germany)와 Dermascan-C (DermaScan-C USB; Cortex Technology $\mathrm{ApS}$, Denmark)를 사용하였다.

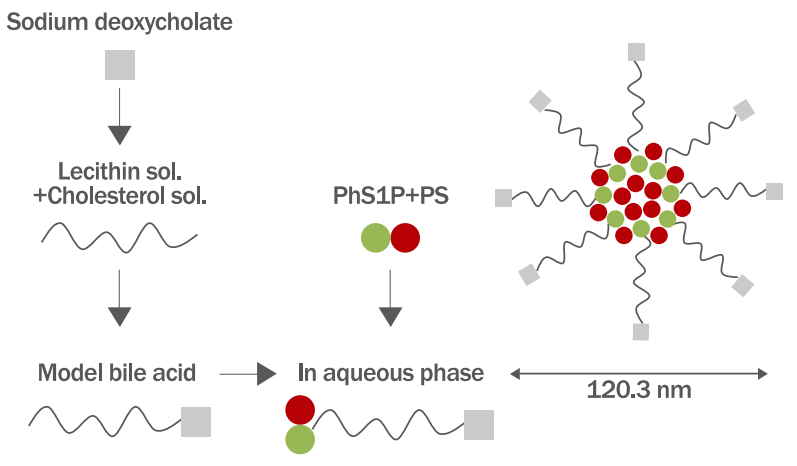

Figure 2. A schematic illustration of the manufacturing process of PhS1P/PS-MBA nanoparticles.

PhS1P/PS-MBA nanoparticles were chemically conjugated to the terminal end of a di-block copolymer composed of MBA and hydrazone bond via two PhS1P/PS cleavable linkages. PhS1P/ PS conjugated MBA di-block copolymers self-assembled to form nanoparticles in aqueous solution. PhS1P, phytosphingosine-1phosphate; PS, phytosterol; MBA, model bile acid.

\section{2. 모델 담즙산의 제조}

모델 담즙산 제조 시 최적조건은 1단계로 $\mathrm{SDC} 5.78 \mathrm{~g}$ 을 25 $\mathrm{mL}$ 메탄올(메탄올 85:물 15의 부피 비)에 혼합하여 $430 \mathrm{mM}$ 의 $\mathrm{SDC}$ 용액을 만든 후 이 용액 $2.25 \mathrm{~mL}$ 와 lecithin 용액 $1.8 \mathrm{~mL}$ (클로로포름 용매에 $100 \mathrm{mg} / \mathrm{mL}$ 로 용해) 및 cholesterol 용액 $1.05 \mathrm{~mL}$ (클로로포름 용매에 $500 \mathrm{mg} / \mathrm{mL}$ 로 용해)를 첨가하여 1 차 용액을 제조하였다. 2 단계로 1 차 용액을 테플론 캡을 가진 유리 튜브에 넣고 $55^{\circ} \mathrm{C}$ 항온수조에서 $5 \mathrm{~h}$ 동안 열처리한 후 질소 가스로 증발시켰다. 3 단계로 증발된 잔여물을 $2 \mathrm{~h}$ 동안 $-70^{\circ} \mathrm{C}$ 로 냉동시킨 후 9 시간 이상 감압 하에서 동결건조하고, $\mathrm{PBS}$ 로 용해 시켜 $4 \mathrm{~h}$ 동안 $56{ }^{\circ} \mathrm{C}$ 에서 열처리 하였다. 마지막 단계로 열처리가 완료된 용액은 무혈청 배지에서 $1: 10$ 으로 희석시키고 $0.45 \mu \mathrm{M}$ 필터를 이용하여 여과 후 최종적으로 모델 담즙산을 제조하였다 (Figure 1).

\section{3. 나노입자의 제조 및 물리화학적 특성 분석}

모델 담즙산-PhS1P/PS 나노입자를 제조하기 위하여 먼저 $\mathrm{PhS} 1 \mathrm{P}$ 와 PS의 함량을 각각 $0.1 \%$ 로하고 Figure 1의 방법으로 제조한 모델 담즙산의 함량을 $0.5-2.0 \%$ 의 범위로 하여 THF에 용해시켰다. 이 용액을 $40^{\circ} \mathrm{C}$ 에서 $3 \mathrm{~h}$ 동안 반응시킨 후 $\mathrm{PhS} 1 \mathrm{P}$ 와 $\mathrm{PS}$ 를 모델 담즙산과 hydrazone bond의 di-block copolymer의 말단에 화학적으로 합성하고, $24 \mathrm{~h}$ 후 용매를 제거하여 최종적 으로 모델 담즙산-PhS1P/PS 나노입자를 제조하였다(Figure 2, Kim et al., 2018).

얻어진 나노입자의 물리화학적 특성(나노입자의 크기 및 입도 

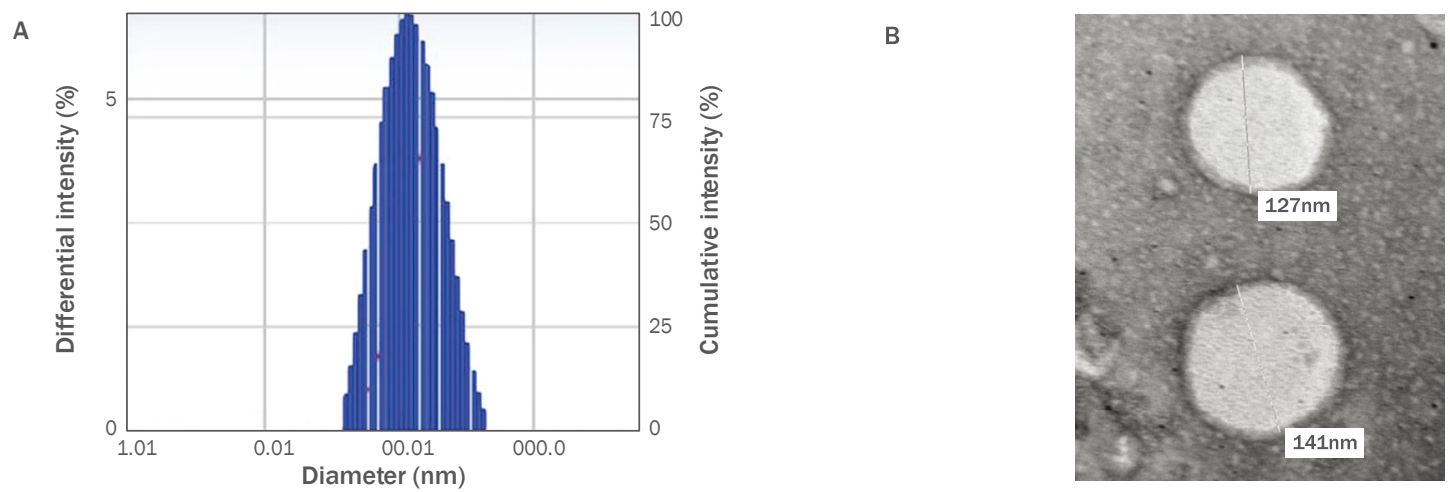

Figure 3. Measurement of particle size distributions and SEM images of PhS1P/PS-MBA nanoparticles.

(A) Size distribution was measured by Photal and ELS-Z and average particle size was about $120.3 \mathrm{~nm}$ in diameter. (B) SEM images of nanoparticles ultimately form uniform spherical particles. SEM, scanning electron microscope. PhS1P, phytosphingosine-1-phosphate; PS, phytosterol; MBA, model bile acid.

분포) 분석을 위하여 $0.45 \mu \mathrm{m}$ 필터로 여과하고 여과량과 동량의 에탄올로 용해시킨 후 용매를 증발시켜 분석용 시료를 만들었고, 분석용 시료는 국제공인시험기관인 한국고분자시험연구소에 의뢰 하였다(Koptri-18-06-10939-1, Koptri-18-07-13030-1).

나노입자 내의 $\mathrm{PhS} 1 \mathrm{P} / \mathrm{PS}$ 의 봉입량과 포집효율은 $\mathrm{HPLC}$ 를 사 용하여 분석하였고, 분석조건은 ZORBAX Eclipse XDB-C18, 5 $\mu \mathrm{m}$ size, $4.6 \mathrm{~mm} \times 150 \mathrm{~mm}$ 컬럼과 이동상으로 메탄올과 정제 수를 $50: 50(\%)$ 혼합 후 사용하였다. 이때 유속을 $0.8 \mathrm{~mL} / \mathrm{min}$ 으 로 하고 $30^{\circ} \mathrm{C}$ 에서 stop time은 $10 \mathrm{~min}$ 으로 하였다. 분석 샘플로 는 표준물질에 메탄올과 정제수를 95:5 (\%)로 혼합 후 사용하였 으며, 시료도 동일 조건으로 하고 $1 \mathrm{~h}$ 동안 초음파처리 후 사용하 였다. 또한 $\mathrm{PhS} 1 \mathrm{P} / \mathrm{PS}$ 농도에 따른 검량선을 작성한 후 다음 식 을 통하여 포집효율을 결정하였다.

포집효율 $(\%)=$ 나노입자에 봉입된 $\mathrm{PhS} 1 \mathrm{P} / \mathrm{PS}$ 량 $\div$ (나노입자에 봉입된 $\mathrm{PhS} 1 \mathrm{P} / \mathrm{PS}$ 량+봉입에 사용한 $\mathrm{PhS} 1 \mathrm{P} / \mathrm{PS}$ 량 $) \times 100$

\section{4. 세포 흡수율 평가}

세포흡수율 평가를 위하여 우선 모델 담즙산-PhS1P/PS 나노
입자를 $2.3 \%$ lecithin, $5.7 \% \mathrm{SDC}, 1.1 \%$ cholesterol, $1 \mu \mathrm{g} / \mathrm{mL}$ $\mathrm{PI}, 10 \mathrm{~mL} \mathrm{PBS}$ 용액의 비율로 $15 \mathrm{~mL}$ conical tube에 넣어 초음 파분산기로 형광물질을 봉입하였다.

인체 피부각질세포주인 $\mathrm{HaCaT}$ 세포는 한양대학교 의과대학 소화기내과 실험실에서 보유한 cell line이며, $10 \%$ fetal bovine serum과 항생제 $(100 \mu \mathrm{g} / \mathrm{mL}$ streptomycin과 $100 \mathrm{U} / \mathrm{mL}$ penicillin)가 첨가된 $\mathrm{DMEM}$ 으로 $37^{\circ} \mathrm{C}, 5 \% \mathrm{CO}_{2}$ 배양기에서 $\mathrm{T} 75$ culture flask로 배양하였고 2 일에서 3 일에 한번씩 분주함과 동 시에 배양액을 교체해 주었다.

$\mathrm{HaCaT}$ 세포는 12 well plate에 $5 \times 10^{4}$ cells/well 농도로 1 $\mathrm{mL} \mathrm{DMEM}$ 에서 배양하였고 $24 \mathrm{~h}$ 이 지난 후에 DMEM 상층액을 제거 및 $1 \mathrm{~mL}$ PBS로 1 회 세척하였다. 대조군은 PI $1 \mu \mathrm{g} / \mathrm{mL}$ 을 포함한 PBS $1 \mathrm{~mL}$ 을 처리하였고, 실험군은 PI-loaded $0.1 \%$ 모 델 담즙산-PhS1P/PS 나노입자를 포함한 PBS $1 \mathrm{~mL}$ 을 처리하 였다. $37^{\circ} \mathrm{C}, 5 \% \mathrm{CO}_{2}$ 배양기에서 $1 \mathrm{~h}$ 동안 배양한 후 $1 \mathrm{~mL} \mathrm{PBS}$ 로 3 번 수세한 후 형광현미경으로 관찰하였다. DAPI는 배양 $1 \mathrm{~h}$ 이 끝나기 $20 \mathrm{~min}$ 전에 모든 well 당 두 방울 떨어뜨려서 배양하 였다.

\section{Table 1. The complete list of ingredients used in the cream formulation}

\section{Total Ingredients contained in $100 \mathrm{~g}$}

Water, Glycerin, Dipropylene glycol, Triethylhexanoin, Isohexadecane, Cyclopentasiloxane, Cetearyl Alcohol, Methyl Gluceth-20, Myristyl myristate, Niacinamide, Sorbitan olivate, Beeswax, Cetearyl olivate, Echinacea purpurea extract, Mourera fluviatilis extract, Crocus sativus flower extract, Palmitoyl tripeptide-1, Palmitoyl tetrapeptide-7, Ceramide NP, Moringa oleifera seed oil, Safflower Oil/Palm oil aminopropanediol esters, Glycosphingolipids, Glycolipids, Phytosphingosine, Hydrogenated lecithin, Caprylic/Capric triglyceride, Phytosterol, Polyglyceryl-10 oleate, Citrus aurantium dulcis (Orange) Peel oil, Citrus limon (lemon) Peel oil, Lavandula angustifolia (Lavender) oil, Eucalyptus globulus leaf oil, Abies sibirica oil, Pelargonium graveolens flower oil, Rosmarinus Officinalis (Rosemary) leaf oil, Rosa damascena flower oil, Eclipta prostrata extract, Melia azadirachta flower extract, Melia azadirachta leaf extract, Curcuma longa (Turmeric) root extract, Ocimum sanctum leaf extract, Corallina Officinalis extract, Cymbopogon schoenanthus oil, Anastatica Hierochuntica extract, Hydrolyzed collagen, Gossypium herbaceum (Cotton) extract, Lactobacillus ferment, Borago Officinalis seed oil, Pentylene glycol, Silica, Ammonium acryloyldimethyltaurate/ VP Copolymer, Cetyl palmitate, Glyceryl stearate, PEG-100 stearate, Sorbitan palmitate, Caprylyl glycol, Hydroxyethylcellulose, Tromethamine, Ethylhexylglycerin, Adenosine, Aluminum hydroxide, Ammonium polyacrylate, Sodium deoxycholate, Sodium nitrate, Butylene glycol, Cholesterol, Disodium phosphate, Polysorbate 60, Sucrose, Arginine, PCA, Serine, Sodium phosphate, Alanine, Threonine, Glyoxal, Gluconolactone, Polysorbate 20, 4-Butylresorcinol, Dextrin, Lecithin, Carbomer, Disodium EDTA, Phenoxyethanol, Sodium benzoate, Titanium dioxide 


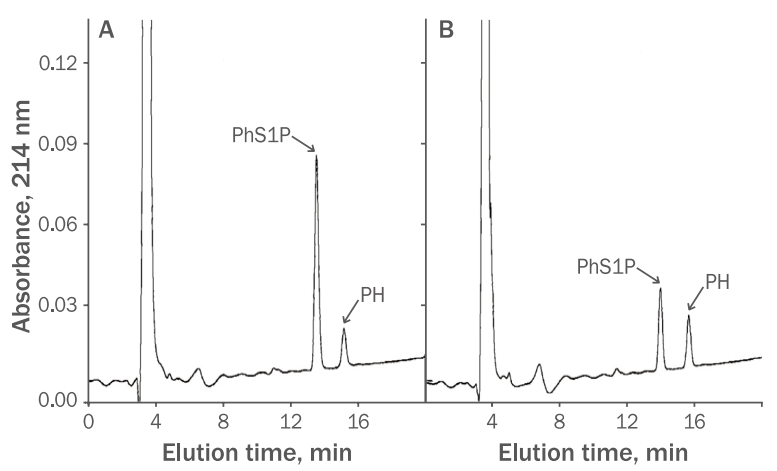

Figure 4. HPLC profile of 2 dominant PhS1P and PS peaks of a standard mixture and PhS1P/PS-MBA nanoparticles.

Chromatograms of standard mixture (a) and nanoparticles (b) are recorded at $214 \mathrm{~nm}$. PhS1P and PS peaks are indicated two marker compounds whose peaks were retained at 13.56 and at $15.58 \mathrm{~min}$, respectively. Correlation coefficients were better than 0.999 for all standard components. The LOD and LOQ for both components were 1.57 and $3.12 \mu \mathrm{g} / \mathrm{mL}$, respectively. The PhS1P and $\mathrm{PH}$ levels in nanoparticles were quantified as 0.037 and 0.026 $\%$, respectively. HPLC, high-performance liquid chromatography; PhS1P, phytosphingosine-1-phosphate; PS, phytosterol; MBA, model bile acid; LOD, limit of detection; LOQ, limit of quantitation.

\section{5. 화장품의 제조 및 인체 피부적용시험}

임상용 화장품은 모델 담즙산-PhS1P/PS 나노입자의 함량을 $3.0 \%$ 로 하여 기기 조건을 $200 \mathrm{rpm}$ 에서 $10 \mathrm{~min}$ 으로 교반 후 크 림 제형을 제조하였고, 이외의 성분들은 크림 제형에 적합한 전 성분으로 구성하였다(Table 1).

피부에서의 효능을 알아보기 위하여 헬싱키 선언에 근거한 윤 리규정, 식품의약품안전처의 의약품, 의약외품, 화장품 및 의 료기기 검사기관 지정 등에 관한 규정, 의약품 임상시험 관리기 준, 화장품 인체적용시험 및 효력시험 가이드라인, 화장품 표시 광고 실증을 위한 시험방법 가이드라인, 기능성화장품의 유효성 평가를 위한 가이드라인, 보건복지부의 생명윤리 및 안전에 관한 법률에 따라 중앙대학교 피엔케이피부임상연구센타(P\&K Skin Research Center)에 의뢰하여 2016년 12월 12일부터 2016년 12 월 27 일까지 피부자극, 피부탄력, 피부두께, 진피치밀도 개선 에 대한 인체 피부적용시험을 실시하였다(PNK-16D12-E1R).
Control : only PI
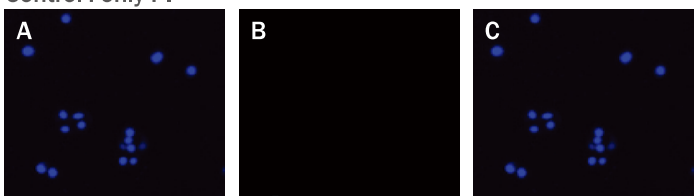

Treatment : PI-PhS1P/PS-MBA nanoparticles

D
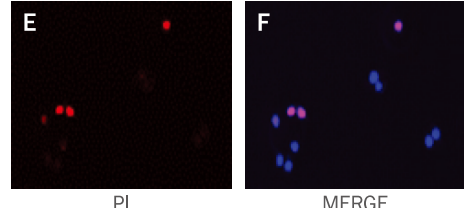

Figure 5. Fluorescence images of HaCaT cells incubated with PIPhS1P/PS-MBA nanoparticles for $1 \mathrm{~h}$.

$\mathrm{HaCaT}$ cells were cultured in the DMEM for $24 \mathrm{~h}$ and then the cells were treated with or without PI-PhS1P/PH-MBA nanoparticels for $1 \mathrm{~h}$. Both untreated and treated cell lines were stained with DAPI and PI and visualized by fluorescence microscope. Intact cell nucleus was visualized by DAPI (A, D) and cell penetrating PhS1P/ PH-MBA nanoparticels were stained using $\mathrm{PI}(\mathrm{B}, \mathrm{E})$. Merge image of both $\mathrm{PI}$ and DAPI double staining were shown in $\mathrm{C}$ and $\mathrm{F}$. Cells were observed at $\mathrm{x} 200$ magnification. PI, propidium iodide; DAPI, 4',6-diamidino-2-phenylindole.

\section{6. 통계분석 방법}

본 실험에 사용한 기기 측정값은 paired $t$-test를 통해 시료 적용 전후의 유의성 여부를 가설평균 차 $5 \%\left({ }^{*} p<0.05\right)$ 로 확인하 였으며, 통계분석 프로그램을 microsoft사 excel 등의 software (ver. 2015)를 사용하였다.

\section{Results and Discussion}

\section{1. 나노입자의 물리화학적 특성 분석}

모델 담즙산- $\mathrm{PhS} 1 \mathrm{P} / \mathrm{PS}$ 나노입자를 제조하여 그 입자 분포 를 Photal ELS-Z로 측정한 결과, 입자의 평균입도가 약 120.3 $\mathrm{nm}$ 임을 알 수 있었다(Figure $3 \mathrm{~A}$ ), 이는 세포간 지질 사이가 100-200 nm인 것을 감안하면 경피흡수가 양호한 나노입자로 확인되었다. 또한, 나노입자의 입도가 너무 미세하여 동결 전자 현미경을 이용하여 촬영한 결과도 나노 크기로 안정화 되었음을

Table 2. The loading efficiency of PhS1P and PS in the PhS1P/PS-MBA nanoparticles with different MBA concentrations

\begin{tabular}{cccr}
\hline MBA & & \multicolumn{2}{c}{ Loading efficiency (\%) } \\
\cline { 2 - 3 } 0.5 & PhS1P & 18.52 \\
1.0 & 25.31 & 36.35 \\
1.5 & 40.52 & 77.31 \\
2.0 & 83.12 & 85.67 \\
\hline
\end{tabular}

PhS1P, phytosphingosine-1-phosphate; PS, phytosterol, MBA, model bile acid. 

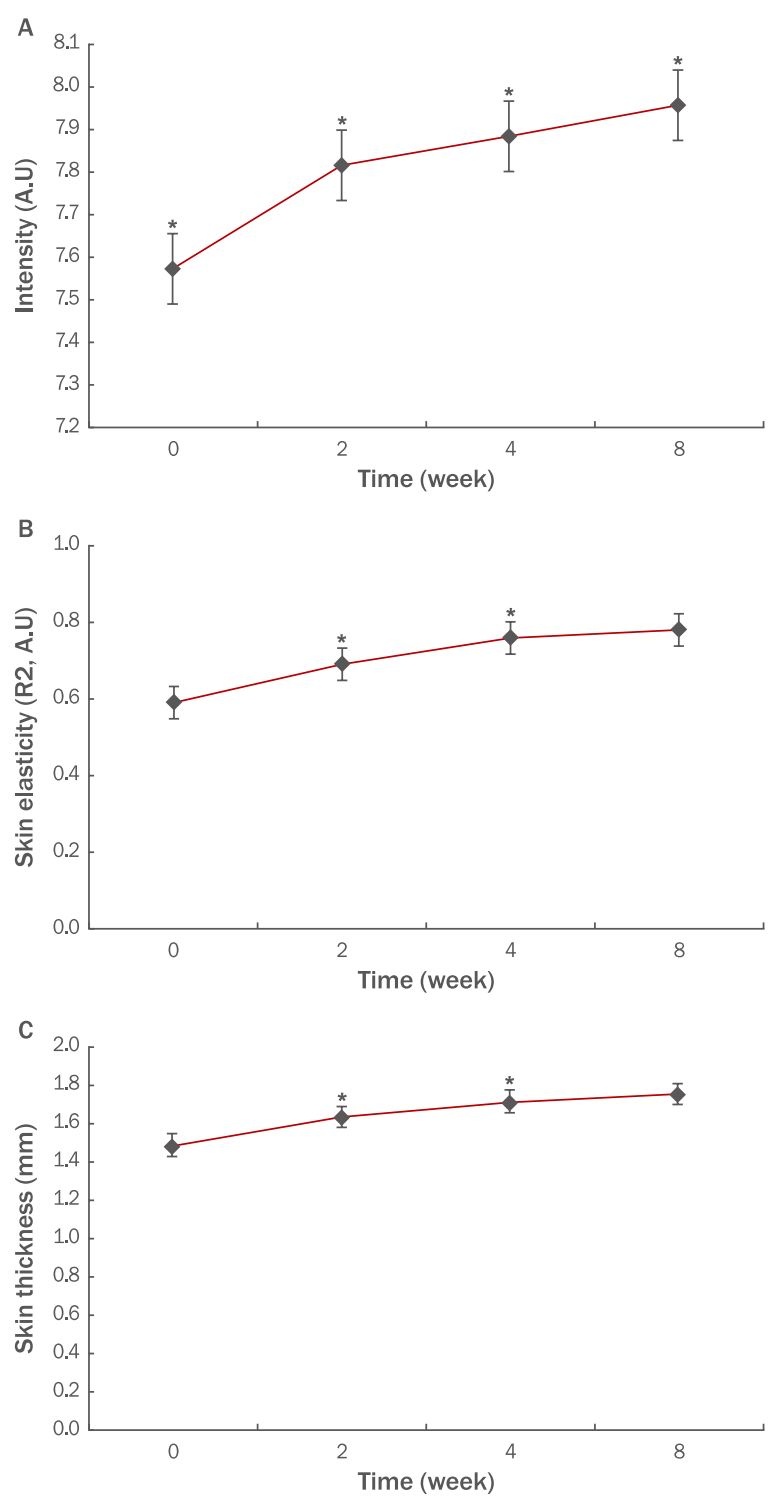

Figure 6. The skin improvement effects of cream formulation. Clinical and instrumental evaluations were done at baseline, after 2, 4 and 8 weeks, and at the end of the study. Skin elasticity, skin thickness and dermal intensity were investigated clinically as well as instrumentally with capacitance measurements. Skin elasticity $(\mathrm{A})$, skin thickness (B) and dermal intensity (C) improved after using cream formulation, respectively $\left({ }^{*} p<0.05\right)$.

확인하였다(Figure 3B).

제조된 모델 담즙산-PhS1P/PS 나노입자 내부에 $\mathrm{PhS} 1 \mathrm{P}$ 와 $\mathrm{PS}$ 의 함량을 $\mathrm{HPLC}$ 로 분석한 결과, 표준물질과 모델 담즙 산-PhS1P/PS 나노입자에서 $\mathrm{PhS} 1 \mathrm{P}$ 와 $\mathrm{PS}$ 의 동일한 피크가 각 각 13.56 및 $15.58 \mathrm{~min}$ 에서 나타나는 것이 확인되어 나노입자 내에 $\mathrm{PhS} 1 \mathrm{P}$ 와 $\mathrm{PS}$ 가 안정적으로 봉입 되었음을 확인하였다. 이 때 두 성분의 검출 한계(limit of detection, LOD)와 정량화(limit of quantitation, $\mathrm{LOQ}$ )는 각각 1.57 와 $3.12 \mu \mathrm{g} / \mathrm{mL}$ 이었고 나 노입자 내의 $\mathrm{PhS} 1 \mathrm{P}$ 와 $\mathrm{PS}$ 의 봉입량은 각각 0.037 과 $0.026 \%$ 이 었다(Figure $4 \mathrm{~A}, 4 \mathrm{~B})$. 또한, 나노입자 내의 $\mathrm{PhS} 1 \mathrm{P}$ 와 $\mathrm{PS}$ 의 포 집효율은 Table 2 와 같이 $\mathrm{PhS} 1 \mathrm{P}$ 가 $\mathrm{PS}$ 보다 함량이 더 높다는 것 을 확인하였고, 모델 담즙산 농도에 따른 봉입효율도 $\mathrm{PhS} 1 \mathrm{P}$ 가 더 큰 것을 알게 되었다. 이것은 모델 담즙산의 농도가 높아질수 록 $\mathrm{PhS} 1 \mathrm{P}$ 및 $\mathrm{PS}$ 의 함량과 봉입효율은 점차 증가하는 것을 의미 한다.

\section{2. 세포 흡수율 평가}

제조한 모델 담즙산-PhS1P/PS 나노입자에 대하여 세포흡 수 여부를 평가하는 방법은 in vitro 피부 투과 실험으로 확인 하였으며, 인체 피부각질세포주인 $\mathrm{HaCaT}$ 세포에 모델 담즙 산-PhS1P/PS 나노입자를 처리한 후 200 배율의 형광현미경으 로 평가하였다(Figure 5).

$\mathrm{PI}$ 가 살아있는 세포에서 세포막에 대한 투과력이 없다는 사 실을 이용하여 대조군 세포(untreated cells)와 실험군 세포 (treated cells)에 PI 단독(Figure 5B) 및 $\mathrm{PI}$ 봉입 모델 담즙 산-PhS1P/PS 나노입자(Figure $5 \mathrm{E}$ )를 각각 $1 \mu \mathrm{g} / \mathrm{mL}$ 의 농도 로 $\mathrm{PI}$ 를 처리 후 $37^{\circ} \mathrm{C}$ 의 $\mathrm{CO}_{2}$ 배양기에서 $1 \mathrm{~h}$ 동안 배양하고 세 포 투과 정도를 live cell image로 관찰한 결과, $\mathrm{PI}$ 군의 대조군은 세포를 투과하지 못하여 흑색으로 나타났고(Figure 5B), PI군 의 실험군은 세포를 투과하여 적색으로 관찰되었다(Figure $5 \mathrm{E}$ ). 그리고 각 대조군과 실험군의 세포를 DAPI로 염색 후 관찰하면 $\mathrm{DAPI}$ 군의 Figure $5 \mathrm{~A}$ 및 $5 \mathrm{D}$ 와 같이 청색으로 나타났다. 이때 각 각의 $\mathrm{DAPI}$ 군과 $\mathrm{PI}$ 군의 이미지를 병합하여 검경하면, merge군 (DAPI군+PI군)의 Figure 5C는 세포 자체의 청색(Figure 5A) 으로 보였고, Figure $5 \mathrm{~F}$ 는 세포 자체의 청색(Figure 5D)과 적 색(Figure $5 \mathrm{E}$ )이 혼합되어 청색과 분홍색(Figure $5 \mathrm{~F}$ )으로 관찰 되었다. 이러한 결과로부터 모델 담즙산-PhS1P/PS 나노입자가 인체 피부각질세포주인 $\mathrm{HaCaT}$ 세포 안으로 투과된다는 사실을 입증하였다.

\section{3. 화장품 제형의 안정성 실험}

모델 담즙산-PhS1P/PS 나노입자의 안정도는 일반적인 화장 품 제제 안정도 테스트방법 중 하나인 $45^{\circ} \mathrm{C}$ 및 $-4^{\circ} \mathrm{C}$ 에서 테스트 하였고, 그 결과 2 개월간 모델 담즙산- $\mathrm{PhS} 1 \mathrm{P} / \mathrm{PS}$ 나노입자들이 제형에서 안정하게 유지되고 있음을 확인하였다. 이는 $\mathrm{PhS} 1 \mathrm{P}$ 및 $\mathrm{PS}$ 을 포함하는 모델 담즙산-PhS1P/PS 나노입자로 만드는 과정과 크림 제형의 안정화 공정을 감안하여 다층유화기술을 제 형에 적용하였기 때문에 가능한 것으로 사료되었다.

또한 $\mathrm{PhS} 1 \mathrm{P}$ 및 $\mathrm{PS}$ 가 다른 화장품 원료들보다 녹는점이 비교 적 높은 소수성의 물질이고 제형화 이후에도 재결정이 일어나는 
등의 많은 문제점과 단점이 있어서 통상의 화장품 제형에는 극미 량을 사용하여 지금까지는 피부장벽 기능과 항염효과를 동시에 발휘하는 제품을 기대하기 어려웠다. 그러나 본 연구에서의 모 델 담즙산-PhS1P/PS 나노입자의 제조와 다층유화기술의 적용 을 통하여 이러한 소수성의 물질을 고함량으로 안정화하고 난용 성 물질들의 가용화와 제형화에 극복하기 어려웠던 난제를 해결 할 수 있었다.

따라서 모델 담즙산-PhS1P/PS 나노입자의 피부지질성분이 피부각질층 내에서 이루고 있는 구조와 동일한 형태로 만들어서 모델 담즙산-PhS1P/PS 나노입자의 유화 후 크림 제형의 전성 분 중 $\mathrm{PhS} 1 \mathrm{P}$ 및 $\mathrm{PS}$ 의 재결정화를 막아줄 뿐만 아니라, 피부 도 포 시 장벽기능을 향상시키고 피부 친화력도 높일 수 있는 것으 로 사료되었다(Table 1).

\section{4. 인체 피부적용시험}

모델 담즙산-PhS1P/PS 나노입자 함량을 $3.0 \%$ 로 하여 크 림 제형을 제조 후 피부에의 효능을 알아보기 위해 피부자극, 피부탄력, 피부두께, 진피치밀도 개선에 대한 인체 피부적용 시험을 실시하였고 Cutometer를 이용하여 피부탄력 측정값 을 분석한 결과, 사용 2 주 후 $17.22 \%$, 사용 4 주 후 $28.85 \%$, 사 용 8 주 후 $39.35 \%$ 로 개선된 것을 확인하였다(Figure $6 \mathrm{~A}$ ). 또 한 Dermascan-C를 이용하여 피부두께와 진피치밀도 측정값 을 분석한 결과, 피부두께는 사용 2 주 후 $10.11 \%$, 사용 4 주 후 $19.57 \%$, 사용 8 주 후 $27.23 \%$ 으로 개선된 것을 확인하였으며 (Figure 6B), 진피치밀도는 사용 2 주 후 $4.52 \%$, 사용 4 주 후 $5.17 \%, 8$ 주 후 $7.17 \%$ 로 개선된 것을 확인하였다(Figure 6C). 모든 실험 결과는 통계적으로 유의한 수준( $\left.{ }^{*} p<0.05\right)$ 으로 확인하 였다.

또한, 모델 담즙산-PhS1P/PS 나노입자가 함유된 크림 제형 에 대한 피부자극 시험은 피부탄력, 피부두께, 진피치밀도 개선 에 대한 인체 피부적용시험을 진행하면서 피부과 전문의에 의한 피부 이상반응 평가 및 피험자들을 대상으로 설문평가를 실시하 였고, 그 결과는 평가 기간 동안에 특별한 피부 이상반응은 나타 나지 않았다.

따라서 모델 담즙산-PhS1P/PS 나노입자가 함유된 크림 제형 은 다양한 기능성을 기대할 수 있는 화장품 제형으로 적합할 것 으로 사료되었고, 모델 담즙산-PhS1P/PS 나노입자는 새로운 피부전달체 소재임을 입증할 수 있었다.

\section{Conclusion}

인간의 삶의 질이 향상되면서 점차 뷰티산업이 활성화되고 남 녀노소 피부미용의 필요성이 증가되어 화장품의 수요 및 공급 또
한 급격하게 팽창하고 있는 반면 화장품의 품질과 유효성은 아직 도 매우 미흡하다고 생각된다. 특히, 무분별한 화장품의 선택과 사용으로 인하여 대부분의 사람들은 자신의 피부가 손상을 받고 있다고 생각하는 경우가 지속적으로 증가하고 있다.

그래서, 본 연구는 피부장벽기능 이상을 효과적으로 개선하 고, 화장품으로서 보다 안전하고 부작용 없이 사용할 수 있는 제품을 개발하는 것을 목적으로 새로운 피부전달체 소재인 모 델 담즙산-PhS1P/PS 나노입자를 생체모방기술(biomimetic technology)로 개발하였으며, 담즙산의 효과적인 계면활성 원리 를 이용하여 생체적 친화도가 높은 피부전달체의 소재로 화장품 제형에 적용하였다.

본 연구에서는 선행연구 결과를 토대로 피부장벽기능에서 가 장 중요한 세라마이드 등 key ingredient mixture의 최적화 비 율을 활용하였고, $\mathrm{PhS} 1 \mathrm{P}$ 와 $\mathrm{PS}$ 를 피부에 안전하게 전달될 수 있 도록 모델 담즙산-PhS1P/PS 나노입자를 제조 후 다층유화기술 의 적용을 통하여 안정적인 화장품을 개발하고, 피부미용 효과를 측정하기 위한 피부 탄력 개선, 피부 두께 증가, 피부치밀도 개 선에 관한 인체 적용실험과 피부자극 여부를 확인하였다. 그 결 과, 피부탄력, 피부두께, 진피치밀도 개선 효과를 입증하였으며 어떠한 피부자극도 없는 것을 확인하였다.

이상의 결과를 바탕으로 화장품 소재로 모델 담즙산-PhS1P/ $\mathrm{PS}$ 나노입자를 새로운 피부전달체로 사용할 수 있음을 확인시켜 주었고, 향후에는 더욱 우수한 품질과 효과적인 화장품을 개발 할 수 있는 기반을 마련할 수 있는 기술을 제공하였다.

\section{Acknowledgements}

이 논문은 2018년도 중소벤처기업부와 서울특별시의 재원으 로 기술개발 지원사업의 지원을 받아 수행된 연구임(과제번호: S2594138).

\section{References}

Bouic PJ. The role of phytosterols and phytosterolins in immune modulation: a review of the past 10 years. Current Opinion in Clinical Nutrition and Metabolic Care, 4: 471-475, 2001.

Cho HJ, Chung BY, Lee HB, Kim HO, Park CW, Lee CH. Quantitative study of stratum corneum ceramides contents in patients with sensitive skin. The Journal of Dermatology, 39: 295-300, 2012.

Chung JY, Han HS. The recent trend of percutaneous absorption used in cosmetics. Asian Journal of Beauty and Cosmetology, 12: 597-605, 2014. 
Chung N, Jenkins G, Hannun YA, Heitman J, Obeid LM. Sphingolipids signal heat stress-induced ubiquitindependent proteolysis. Journal of Biological Chemistry, 275: 17229-17232, 2000.

Coderch L, López O, de la Maza A, Parra JL. Ceramides and skin function. American Journal of Clinical Dermatology, 4: 107-129, 2003.

Han NR, Kim HM, Jeong HJ. The $\beta$-sitosterol attenuates atopic dermatitis-like skin lesions through downregulation of TSLP. Experimental Biology and Medicine, 239: 454-464, 2014.

Hjelm RP, Schteingart C, Hofmann AF, Silvia DS. Form and structure of self-assembling particles in monoolein-bile salt mixtures. The Journal of Physical Chemistry, 99: 16395-16406, 1995.

Hofmann AF, Small DM. Detergent properties of bile salts: correlation with physiological function. Annual Review of Medicine, 18: 333-376, 1967.

Hofmann AF, Mysels KJ. Bile acid solubility and precipitation in vitro and in vivo: the role of conjugation, $\mathrm{pH}$, and $\mathrm{Ca}^{2+}$ ions. Journal of Lipid Research, 33: 617-626, 1992.

Kim DM, Yun JS, Han IS. Composition for external skin application for preventing pigmentation and promoting skin regeneration and a manufacturing method thereof. Korea Patent 10-2018-0170393, 2018.12.27.

Kim HJ. The functional cosmetics and process used biles and jahageo-the Chinese medicine named the navel cord. Korea Patent 10-2003-0020270, 2003.03.31.

Lee JP, Cha HJ, Lee KS, Lee KK, Son JH, Kim KN, Lee DK, An S. Phytosphigosine-1-phosphate represses the hydrogen peroxide-induced activation of c-Jun-Nterminal kinase in human dermal fibroblasts through the phosphatidylinositol 3-kinase/Akt pathway. Archives of Dermatological Research, 304: 673-678, 2012.

Lee MN, Yang KW, Lee IH. Assessment of efficacy of $5 \mathrm{~nm}$ class nano gold essence cosmetics. Asian Journal of Beauty and Cosmetology, 14: 259-266, 2016.

Loizou S, Lekakis I, Chrousos GP, Moutsatsou P. $\beta$-Sitosterol exhibits anti-inflammatory activity in human aortic endothelial cells. Molecular Nutrition Food Research, 54: 551-558, 2010.
Mi LZ, Devarakonda S, Harp JM, Han Q, Pellicciari R, Willson TM, Khorasanizadeh S, Rastinejad F. Structural basis for bile-acid binding and activation of the nuclear receptor FXR. Molecular Cell, 11: 1093-1100, 2003.

Nurunnabi Md, Khatun Z, Revuri V, Nafiujjaman MD, Cha $\mathrm{S}$, Cho S, Huh KM, Lee Y. Design and strategies for bile acid mediated therapy and imaging. Royal Society of Chemistry Advances, 6: 73986-74002, 2016.

Pata MO, Hannun YA, Ng CK. Plant sphingolipids: decoding the enigma of the Sphinx. The New Phytologist, 185: 611-630, 2010.

Pyne S, Pyne NJ. Sphingosine 1-phosphate signalling in mammalian cells. The Biochemical Journal, 349: 385402, 2000.

Roda A, Hofmann AF, Mycels KJ. The influence of bile salts structure on self-association in aqueous solution. The Journal of Biological Chemistry, 258: 6362-6370, 1983.

Setchell KDR, Kritchevsky D, Nair PP. The bile acids: chemistry, physiology and metabolism-Volume 4: methods and applications. Springer US, New York, pp122-145, 1988.

Shin JH, Choi GS, Kang WH, Myung KB. Sphingosine 1-phosphate triggers apoptotic signal for B16 melanoma cells via prolonged ERK and caspase activation. Journal of Korean Medical Science, 22: 298-304, 2007.

Stamp D, Jenkins G. Chapter 1: An overview of bile-acid synthesis, chemistry and function. In: Bile acids: toxicology and bioactivity. Jenkins GJ, Hardie $\sqcup$ (eds.), Royal Society of Chemistry, Cambridge, pp1-13, 2008.

Yun JS, Kim DM, Han IS. Fast releasing micellar nanoparticle and a cosmetic composition comprising it. Korea Patent 10-2017-0143761, 2017.10.31.

Yun JS, Kim DM. Multifuntional sun formulation composition. Korea Patent 10-2018-0103402, 2018a.08.31.

Yun JS, Kim DM. 17 materials of oriental medicine fermentated cosmetic composition and method for preparing thereof. Korea Patent 10-2018-0113465, 2018b.09.21.

Yun JS, Kim DM, Han IS. Fast releasing micellar nanoparticle and a cosmetic composition comprising it. International Patent PCT/KR 201801163, 2018.10.01. 


\section{국문초록}

\section{모델 담즙산 나노입자 기반의 새로운 피부전달체}

김동명 ${ }^{*}$, 윤종성 ${ }^{1}$, 김서주 ${ }^{2}$, 최호순 $^{2}$, 한인석 $^{3}$

${ }^{1}$ 한양대학교 XYZ인체과학연구센터, 서울, 한국

${ }^{2}$ 한양대학교 의과대학 소화기내과, 서울, 한국

3 한양대학교 자연과학대학교 화학과, 서울, 한국

목적: 모델 담즙산-PhS1P/PS 나노입자를 함유한 화장품 제형화 및 생체 내 효능을 평가하기 위하여 소수성인 담즙산의 주성분인 sodium deoxycholate 및 cholesterol과 lecithin을 기반으로 한 phytosphingosine-1-phosphate (PhS1P) 및 phytosterol (PS)을 효 과적인 피부전달체로 개발하고자 한다. 방법: $\mathrm{PhS1P}$ 및 $\mathrm{PS}$ 는 초음파 처리 방법에 의해 모델 담즙산-PhS1P/PS 나노입자에 봉입 되었다. 모델 담즙산-PhS1P/PS 나노입자의 피부침투율을 평가하기 위해 franz diffusion cell 실험을 수행하였고 원료에 대한 적용 가능성을 알아보았다. 모델 담즙산-PhS1P/PS 나노입자는 입도 분석기, SEM 및 HPLC 실험으로 특성을 분석하였고, 피부에 대한 효과를 확인하기 위하여 최종 시제품으로 임상평가를 진행하였으며, Cutometer 및 Dermascan-C를 사용하여 피부의 탄력, 피부 의 두께 및 진피 치밀도를 측정하여 그 개선 효과를 확인하였다. 결과: 모델 담즙산-PhS1P/PS 나노입자를 $85 \%$ 의 높은 수율로 제 조하였으며 평균직경이 약 $120.3 \mathrm{~nm}$ 로 확인되어 $\mathrm{PhS1P}$ 및 PS의 피부세포 침투효과가 대조군 보다 더 우수함을 입증하였다. 이 사 실로부터 모델 담즙산-PhS1P/PS 나노입자가 피부세포로 침투되어 PhS1P 및 PS로 나뉘어 방출되고 진피세포로 쉽게 흡수된다는 것을 알 수 있었고, 피부에 대한 나노입자의 안전성 평가와 피부의 탄력, 피부의 두께 및 진피 치밀도 개선효과와 이상 증상이 없음 을 관찰하였다. 따라서 모델 담즙산-PhS1P/PS 나노입자는 훌륭한 피부전달체 및 화장품 소재임을 확인하였다. 결론: 화장품 제형 에 모델 담즙산-PhS1P/PS 나노입자를 사용함으로써 유효성분의 피부흡수 및 전달이 용이하였으며, 향후 화장품에 적용할 수 있 는 중요한 소재로 기대할 수 있다.

핵심어: 스핑고신포스페이트, 피테스테롤, 모델 담즙산, 나노입자, 피부전달체

이 논문은 2018년도 중소벤처기업부와 서울특별시의 재원으로 기술개발 지원사업의 지원을 받아 수행된 연구임(과제번호: S2594138).

\section{참고문헌}

김동명, 윤종성, 성기훈, 한인석. 피토스핑고신포스페이트 $(\mathrm{PhS} 1 \mathrm{P}) /$ 피토스테롤(PS)을 봉입한 모델담즙산 나노입자 및 민 감성 피부를 위한 피부전달체에 관한 연구. 한국화장품미용학회지, 14: 48-52, 2017.

김동명, 윤종성, 한인석. 색소침착 방지 및 피부재생 촉진을 위한 피부 외용제 조성물 및 피부 외용제 제조방법. 특허출원 번호 10-2018-0170393, 출원일 2018.12.27.

김효진. 담즙과 자하거 성분을 이용한 기능성 화장제 및 그 제조방법. 특허출원번호 10-2003-0020270, 출원일 2003.03.31.

신정현, 이현숙, 최광성. 스핑고신 1-포스페이트(Sphingosine 1-phosphate)에 의한 B16 흑색종 세포의 ERK 활성화. 대한피부과학회지, $46: 298-304,2008$.

윤종성, 김동명, 한인석. 속효성 마이셀 나노 입자 및 이를 포함하는 화장료 조성물. 특허출원번호 10-2017-0143761, 출원일 2017.10.31.

윤종성, 김동명. 다기능성 썬 제형 조성물. 특허출원번호 10-2018-0103402, 출원일 2018a.08.31.

윤종성, 김동명. 17 가지 한방소재 발효 화장품 조성물 및 그 제조방법. 특허출원번호 10-2018-0113465, 출원일 
Transdermal Delivery System of Bile Acid-Conjugated Nanoparticle Model

2018b.09.21.

이미나, 양기욱, 이인희. $5 \mathrm{~nm}$ 급 Nano Gold Essence 화장품의 유효성 평가. 아시안뷰티화장품학술지, 14: 259-266, 2016.

정지연, 한효선. 화장품의 경피 흡수에 대한 최신 연구 동향. 아시안뷰티화장품학술지, 12: 597-605, 2014. 


\section{中文摘要}

\section{模型胆汁酸纳米粒子的新皮肤传达体}

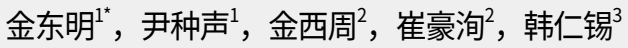

1汉阳大学医学院XYZ人类科学研究中心, 首尔, 韩国

2汉阳大学医学院内科, 首尔, 韩国

3汉阳大学自然科学学院化学系, 首尔, 韩国

目的: 为评价含模型胆汁酸纳米粒子的化妆品配方以及体内功效, 开发以 sodium deoxycholate, cholesterol 和卵磷脂(lecithin)为基础的phytosphingosine-1-phosphate (PhS1P) 和phytosterol (PS)的透皮递送系统。方 法: 通过超声处理将PhS1P/PS加载到胆汁酸结合的纳米颗粒(PhS1P/PS-MBA纳米颗粒) 模型中。进行Franz扩 散池实验以评价制备的纳米颗粒的皮肤渗透功效并探索原料的适用可行性。使用粒度分析仪，扫描电子显微镜 和高效液相色谱系统确认纳米颗粒。为了理解纳米颗粒对皮肤的有效性, 我们使用成品在人类志愿者中进行了 体内试验。通过使用Cutometer (Courage+Khazaka electronic GmbH，Germany)检测皮肤的弹性, 厚度和 皮肤密度来确认皮肤的改善效果。结果：通过测试证实，纳米颗粒可以成功制备，产率为 $85 \%$ ，直径约为 120.3 $\mathrm{nm}$ 。该产品显示出比对照更有效的皮肤渗透, 从而表明细胞内更容易摄取并且裂解的PhS1P/PS伴随快速释放 到人体皮肤中。检查纳米颗粒在人体皮肤上的安全性评估, 弹性, 厚度和皮肤密度, 以测试纳米颗粒对化妆品 的可能适用性。没有观察到不良症状。结论: 因此, 建议化妆品在配方中使用PhS1P/PS-MBA纳米粒子, 以便更 容易吸收到皮肤中。我们的实验证实，这种新材料可能对人体皮肤有重要影响。

关键词: 磷酸鞘氨醇，植物甾醇，模拟胆汁酸，纳米粒子，皮肤传达体 
